\title{
SERUM MAGNESIUM AND CALCIUM STATUS AMONG TERM ASPHYXIATED NEWBORNS WITH MODERATE TO SEVERE HYPOXIC-ISCHEMIC ENCEPHALOPATHY (HIE)
}

\author{
ZAMAN R ${ }^{1}$, MOLLAH AH ${ }^{2}$, CHOWDHURY MMR ${ }^{3}$, YEASMIN $\mathrm{S}^{4}, \mathrm{CHOWDHURY} \mathrm{AS}^{5}$, SAHA D ${ }^{6}$
}

\begin{abstract}
Background \& objective: Perinatal asphyxia affects all organs of the body and brain is the most affected organ. The study was undertaken to find out the status of serum magnesium and calcium level and their significant association among asphyxiated term newborns with moderate to severe HIE.

Material \& methods: The Cross sectional study was done in the Department of Neonatology, Dhaka Medical College Hospital during January 2012 to July 2012. A total of 102 asphyxiated term neonates were enrolled, who has $H / O$ perinatal asphyxia and had Apgar score of 6 or $<6$ at 5 minutes. Clinical grading of HIE into moderate and severe was done according to modified Sarnat and Sarnat scoring system. Under aseptic precautions with standard protocol, estimation of serum magnesium and calcium level in venous blood was done at 48 hours and $7^{\text {th }}$ day of birth. Among the study population, 17 patients had died during follow up and 4 patients were absconded. Finally 81 patients were evaluated by both blood samples though initial 102 cases were evaluated by their first sample. 50 normal healthy infants were also evaluated for serum magnesium and calcium at their 48 hours of birth. Chi-square test was used to assess statistical significance, Pearson correlation coefficient test was done to find out correlation between serum magnesium and calcium status and APGAR score \& $t$ test was done to assess the comparison between the values of serum magnesium and calcium found on two occasions.
\end{abstract}

Results: Of 102 cases majority (58\%) were male. Most of the cases (65.68\%) were moderate HIE. Mean serum magnesium was 1.36(0.9-2.8) $\mathrm{mg} / \mathrm{dl}$ and 1.16(.88-2.6) $\mathrm{mg} / \mathrm{dl}$ among HIE II and HIE III respectively ( $p<0.05)$. Mean serum calcium of HIE II and HIE III were 7.14(5.1-9.6) $\mathrm{mg} / \mathrm{dl}$ and $6.58(5.3-9.0) \mathrm{mg} / \mathrm{dl}$ respectively $(p<0.05)$. There is positive correlation with individual APGAR score with serum magnesium ( $r=0.229, p=0.02)$ and serum calcium $(r=0.231, p=0.019)$ level. Hypocalcaemia was found $35.82 \%$ and $57.14 \%$ among HIE II And HIE III cases respectively(p<0.01). Hypomagnesaemia was found $28.36 \%$ and $45.71 \%$ among HIE II and HIE III $(p<0.05)$.

Conclusion: Hypomagnesaemia and hypocalcaemia are significantly associated with the degree of severity of HIE.

Key words: HIE( hypoxic-ischaemic encephalopathy), calcium, magnesium, asphyxia.

J Dhaka Med Coll. 2017; 26(2) : 148-152

\section{Introduction:}

Perinatal asphyxia is a common problem in the developing countries as in Bangladesh that causes significant morbidity and morbidity. In Bangladesh data on incidence and prevalence of perinatal asphyxia are limited. In Bangladesh overall morbidity of asphyxiated cases was $27.4 \%$. Whereas $40 \%$ of HIE II and HIE III cases survived $^{1}$. It is the third major cause of neonatal death- after infections and preterm births in developing countries and accounts for an estimated $23 \%$ of an annual 4 million neonatal

1. Dr. Rifat Zaman, Junior Consultant (Pediatrics), Dhaka Medical College Hospital, Dhaka.

2. Prof. Md. Abid Hossain Mollah, Professor and Head, Department of Pediatrics, Ibrahim Medical College, Dhaka.

3. Dr. Mohammad Mahfuzur Rahman Chowdhury, Assistant Professor of Urology, Dhaka Medical College, Dhaka.

4. Dr. Shamima Yeasmin, Registrar (Pediatrics), Dhaka Medical College Hospital, Dhaka.

5. Dr. Abu Sayeed Chowdhury, Junior Consultant ( Pediatrics), 500 Bed General Hospital, Mugda, Dhaka.

6. Dr. Dipa Saha, Assistant Professor of Pediatrics, Bashundhara Ad-din Medical College, Dhaka.

Address of Correspondence: Dr. Rifat Zaman, Junior Consultant (Pediatrics), Department of Pediatrics, Dhaka Medical College Hospital, Dhaka, E-mail: dr.rifatzaman.bd@gmail.com, Mobile: +8801727229022

Received: 21 March 2017

DOI: http://dx.doi.org/10.3329/jdmc.v26i2.38833 
deaths ${ }^{2}$. Hypoxic-ischemic encephalopathy (HIE) occurs as a result of hypoxic and/ or ischemic insults during labor and delivery. Primary neuronal injury occurs during the process of asphyxia and stops with resuscitative measures. Secondary neuronal injury continues for hours to days, even after reversal of the asphyxia event. Magnesium is a naturally occurring NMDA receptor antagonist that blocks neuronal influx of calcium within the ion channels which prevent irreversible neuronal injury. Hypocalcaemia is a widely known feature of asphyxiated infants with lower values, developing in infants with more severe signs of asphyxia ${ }^{3}$. After delivery, calcium levels start decreasing and reaches a nadir of $7.5-8.5 \mathrm{mg} /$ dl in healthy term babies, by day 2 of life. Normal levels of serum calcium are regained by day 3 of life. This transition process is responsible for the increased risk of early onset hypocalcemia in high-risk neonates including infants with perinatal asphyxia ${ }^{4}$. The pathophysiology of perinatal hypoxic-ischemic insults has been investigated exhaustively to identify the components that must be blocked to reduce neurologic injury in the newborn ${ }^{5}$. Magnesium and calcium derangements are a frequent finding in asphyxiated infants, and these abnormalities are significantly associated with a poor outcome ${ }^{3}$. So the aim of this study is to assess serum calcium and magnesium of asphyxiated neonate $\&$ to see the association with HIE.

Material \& methods: The Cross sectional study was done in the Department of Neonatology, Dhaka Medical College Hospital from January 2012 to July 2012. A total of 102 asphyxiated term neonates, who fulfilled the inclusion criteria with neonates with history of perinatal asphyxia having gestational age 37 weeks or more, postnatal age up to 48 hours $5 \mathrm{~min}$ APGAR score 6 or $<6$ were selected as cases by purposive sampling. Preterm, intrauterine growth retardation and congenital abnormality were excluded. A written informed consent was taken from parents of neonate before enrollment $\&$ gestation age, birth weight relevant perinatal history, examination findings were recorded in predesigned questionnaire. The post asphyxiated neonates were managed according to neonatal resuscitation protocol. Clinical grading of HIE into moderate and severe was done according to modified Sarnat and Sarnat scoring system. Under aseptic precautions with standard protocol, estimation of serum magnesium and calcium level in venous blood was done at 48 hours and $7^{\text {th }}$ day of birth. Among the study population, 17 patients had died during follow up and 4 patients were absconded. Finally 81 patients were evaluated by both blood samples though initial 102 cases were evaluated by their first sample. On 48 hours and $7^{\text {th }}$ day of birth under aseptic precautions with standard protocol $3 \mathrm{ml}$ blood was drawn and was quantitative determination of serum magnesium and calcium. It was done by fully automatic analyzer( Dimension RxL Max- Siemens). The magnesium method was a modification of the methylthymol blue (MTB) complexometric procedure. The calcium method was a modification of the o-cresolphthelin complexone reaction to a calorimetric calcium assay. 50 normal healthy infants were also evaluated for serum magnesium and calcium at their 48 hours of birth. After collection all the data were checked and edited. Then data were entered into computer with the help of software SPSS for windows programmed version 16.0. Chi-square test was used to assess statistical significance, Pearson correlation coefficient test was done to find out correlation between serum magnesium and calcium status and APGAR score \& $t$ test was done to assess the comparison between the values of serum magnesium and calcium found on two occasions.

\section{Result:}

Initially a total of 102 patients (cases) were selected according to selection criteria and were enrolled as study cases. Majority of the cases had moderate HIE 67(65.68\%). Severe i.e HIE III found in 35(34.32\%) cases. More than half of the study subjects were male (58.0\%). Majority of the study subjects were in-between 30 minutes to 24 hours age group (65\%) followed by 24 to $48 \mathrm{hrs}$ age group $23 \%$. Only $12 \%$ were $<30 \mathrm{~min}$ age. In most cases the mode of delivery was NVD (71.6\%). Majority 66.67\% ( 68 ) of asphyxiated neonates were born of primigravida mother. One third cases it was LUCS $(27.4 \%)$ 
Table-I

Serum level of calcium and magnesium of 48 hours sample.

\begin{tabular}{lcccccc}
\hline Neonates & \multicolumn{2}{c}{ Serum calcium } & & \multicolumn{3}{c}{ Serum magnesium } \\
\cline { 2 - 3 } & Mean & Hypocal- & & Mean & Hypomag- & Hypermag \\
& $\mathrm{mg} / \mathrm{dl}$ & caemia & & $\mathrm{mg} / \mathrm{dl}$ & & $\begin{array}{c}\text { Hesaemia } \\
\text { nesaemia }\end{array}$ \\
\hline HIE II $(\mathrm{n}=67)$ & $7.14(5.1-9.6)$ & $24(35.82 \%)$ & $1.36(0.9-2.8)$ & $19(28.36 \%)$ & $5(7.46 \%)$ \\
HIE III $(\mathrm{n}=35)$ & $6.58(5.3-9.0)$ & $20(57.14 \%)$ & $1.16(.88-2.6)$ & $16(45.71 \%)$ & $3(8.57 \%)$ \\
Healthy neonates $(\mathrm{n}=50)$ & $7.62(6.02-9.2)$ & $6(12 \%)$ & $1.68(1.2-2.8)$ & $4(8 \%)$ & $3(6 \%)$ \\
\hline
\end{tabular}

and only $0.98 \%$ cases it was instrumental. Among the cases obstructed labor was found major risk factor $(42.16 \%)$ following prolonged labor $(28.43 \%)$ \& Meconium stained liquor $(26.47 \%)$.In most cases there were overlapping of risk factor. Majority of the cases had moderate APGAR score ( score 4,5 and 6). It was 72 (70.59\%). There was positive correlation between individual APGAR score with serum calcium and magnesium ie. lower level of serum calcium and magnesium in cases of lower APGAR score and which were statistically significant $(\mathrm{p}<0.05)$. Mean serum magnesium was $1.36 \pm 0.36(0.9-2.8) \mathrm{mg} / \mathrm{dl}$ and $1.16 \pm 0.27$ (.88-2.6) $\mathrm{mg} / \mathrm{dl}$ among HIE II and HIE III respectively $(\mathrm{p}<0.05)$. Mean serum calcium of HIE II and HIE III were 7.14 \pm 0.94 (5.1-9.6) mg/ $\mathrm{dl}$ and $6.58 \pm 0.78$ (5.3-9.0) $\mathrm{mg} / \mathrm{dl}$ respectively $(\mathrm{p}<0.05)$. Hypocalcaemia was found $35.82 \%$, $57.14 \%$ and $12 \%$ among HIE II, HIE III and healthy cases respectively $(\mathrm{p}<0.01)$. Hypomagnesaemia was found $28.36 \%$ and $45.71 \%$ among HIE II and HIE III ( $<<0.05)$. But in healthy neonates hypomagnesaemia was only $8 \%$. Among the HIE II and HIE III cases hypermagnesaemia was $7.46 \%$ (5) and $8.57 \%(3)$ respectively.

\section{Discussion:}

In this study 102 asphyxiated term moderate to severe HIE babies were evaluated for serum calcium and magnesium level. The frequency of HIE II and HIE III was $65.68 \%$ and $34.31 \%$ respectively. But Mia et $\mathrm{al}^{1}$ described the frequency $26.7 \%, 36.3 \%$ and $37 \%$ among stage I, stage II and stage III cases in their study. They were included all the cases in their study. But in this study mild cases (HIE I) were excluded.
Parity may be an important risk factor as newborn of primipara had higher incidence of perinatal asphyxia. This fact is reflected in my study which showed that $66.67 \%$ of asphyxiated neonates were born of primigravida mother and $33.33 \%$ born of multigravidae. Similar findings were found in other studies $\left(\right.$ Daga $^{6}$ and Chowdhury et $\mathrm{al}^{7}$ ). Less expansibility in the birth canal in primigravidae with the consequence of prolongation of labour might have some causal relationship with the high incidence of perinatal asphyxia in this group. Risk factor of perinatal asphyxia were analyzed in study by Batra et $\mathrm{al}^{8}$ in 2000 as obstructed labor in $38.23 \%$ meconium stained amniotic fluid $32.35 \%$ prolong labor in $12.74 \%$, pregnancy induced HTN in $12.54 \%$ and assisted delivery in $7.84 \%$ of cases. In present study obstructed labour (42.16\%) was found as major risk factor followed by prolonged labor \& meconium stained amniotic fluid, pregnancy induced HTN (18.2\%). In both studies showed similar risk factor for perinatal asphyxia, this similarity may be due to same geographical factor, common health problems in the subcontinent. Khreisat $\mathrm{WH}$ et al ${ }^{9}$ conducted his study in Jordan and noted IUGR, antepartum hemorrhage and maternal toxemia were associated with higher incidence of asphyxia. All the above authors stated the fact that regular antenatal visits and early identification of risk factors throughout pregnancy can have a positive impact on the incidence of birth asphyxia. In present study major risk factor was found obstructed labor for this reason most of the delivery were conducted in $\mathrm{DMCH}(46 \%)$ and other hospital $(42 \%)$. Most of the mother had regular antenatal checkup and antenatal health were found 
uneventful in $70.6 \%$. In this study 50 healthy babies were evaluated for serum magnesium and calcium level to standardized the result. Here mean serum magnesium was $1.68 \pm 0.25$ $(1.2-2.8 \mathrm{mg} / \mathrm{dl})$ and mean serum calcium was $7.62 \pm 0.82(6.02-9.2 \mathrm{mg} / \mathrm{dl})$. Cléa R. et $\mathrm{al}^{5}$ stated serum magnesium was $1.7 \mathrm{mg} / \mathrm{dl}$ and Ariceta G. et $\mathrm{al}^{10}$ found mean serum magnesium was $1.74 \pm 0.22$. Onyiriuka $\mathrm{AN}^{11}$ stated mean serum calcium in healthy neonates was $8.04+0.24$. Healthy term babies undergo a physiological nadir in serum calcium levels by 24-48 hours of age. This nadir may be related to the delayed response of parathyroid and calcitonin hormones in a newborn. This nadir may drop to hypocalcemic levels in infants with perinatal asphyxia.

102 asphyxiated term moderate to severe HIE babies were evaluated for serum calcium and magnesium level. The mean serum magnesium on second day of birth was $1.36 \pm 0.36$ and $1.16 \pm 0.27$ for HIE II and HIE III respectively which were statistically significant. Ilves et $\mathrm{al}^{12}$ showed that distressed infants with a severe or moderate degree of hypoxic-ischemic encephalopathy (HIE) had significantly lower concentrntions of magnesium compared to the control group. In this study significant hypomagnesaemia was found $28.36 \%$ and $45.71 \%$ among HIE II and HIE III respectively. Hypermagnesaemia was also found $7.46 \%$ and 8.57\% among HIE II and HIE III respectively, but the result was not significant. There is positive correlation between serum magnesium with HIE status. In our study hypocalcaemia is srongly associated with moderate to severe HIE. Ilves et $\mathrm{al}^{3}$ showed hypo magnesaemia in significant percentage of HIE infants. Tsang et al ${ }^{13}$ and Geven et $1^{14}$ also found hypomagnesaemia while Bachman et $\mathrm{al}^{15}$ described hypermagnesaemia. The decreased concentrations of total $\mathrm{Mg}$ may be involved in the development of $\mathrm{HIE}$, as $\mathrm{Mg}$ takes part in the biochemical cascade after hypoxicischaemic insult. Asphyxia can disturb the neurone's ability to maintain its membrane potential and reduce magnesium blockade of the NMDA receptor and result in increased calcium entry, which is the key mechanism in delayed cell death in asphyxiated infants . Our data about hypomagnesaemia in infants with moderate to severe HIE and later poor outcome support the link between hypomagnesaemia and neuronal injury. The causes of the low total $\mathrm{Mg}$ concentrations in blood serum are not clear, but the duration and severity of hypoxicischaemic insult seems to influence the serum total $\mathrm{Mg}$ concentration. The decreased concentrations of total $\mathrm{Mg}$ may be involved in the development of HIE, as Mg takes part in the biochemical cascade after hypoxicischaemic insult.

In the present study mean serum calcium on second day of birth was $7.14 \pm 0.94$ and $6.58 \pm 0.78$ among HIE II and HIE III respectively which were significant. And hypocalcaemia was found $35.82 \%$ and $57.14 \%$ among them. Ilves et $\mathrm{al}^{3}$ found hypocacaemia in $23 \%$ of asphyxiated infants. But Shah et $\mathrm{al}^{16}$ reported only $11.7 \%$ hypocalcaemic in hppoxic ischemic encephalopathy. Sankaran et $\mathrm{al}^{17}$ estimated $43 \%$ hypocalcaemic which was comparable to our study. Basu P et al ${ }^{18}$ and Jajoo et al ${ }^{19}$ showed a significant low serum calcium levels in asphyxiated babies than controls. Hypocalcaemia is a widely known feature of asphyxiated infants with lower values, developing in infants with more severe signs of asphyxia. There is positive correlation between serum calcium with HIE status i.e. severe HIE cases were suffer more hypocalcimia. In our study hypocalcaemia is srongly associated with moderate to severe HIE. In this study a second sample of blood was drawn on seventh day of birth. The mean serum magnesium and calcium were significantly high. Probably this was due to management of that asphyxiated neonate accordingly. But some cases were persistently in lower value. According to our data, low total $\mathrm{Mg}$ and low total Ca concentrations on the second day of life correlated with the severity of HIE and poor outcome.

\section{Conclusion:}

Magnesium and calcium derangements are significantly found in term asphyxiated infants with moderate to severe HIE. Hypomagnesaemia and hypocalcaemia are significantly associated with the degree of severity of HIE. It can be recommended for routine determination of 
serum magnesium and calcium level in asphyxiated infants for a better outcome prediction.

\section{References:}

1. Mia AH, Hoque MM, Jahan I, Khan FH, Akter KR, Chowdhury MAKA. Outcome of different grade of perinatal asphyxia in a tertiary care hospital. DS (Child) H J 2010; 26(2): 87-89.

2. Lawn JE, Cousens S, Zupan J. Four million neonatal death:When? Where? Why? The Lancet Neonatal Survival series-1. 2005; 365:891-900.

3. Ilves P, Kiisk M, Soopold T. and Talvik T. Serum total magnesium and ionized calcium concentrations in asphyxiated term newborn infants with hypoxicischemic encephalopathy. Acta Paediatr. 2000; 89: 680-5.

4. Jain A, Agarwal R, Sankar MJ, Deorari A, Paul VK. Hypocalcemia in the newborn. Indian J Pediatr .2010 ; 77: 1123-1128.

5. Cléa R, Leone, Naila O.E. Barbosa. Magnesium and Perinatal Asphyxia. NeoReviews. September 2007;8(9):387-393.

6. Daga, A.S., 1990. Risk assessment in birth asphyxia. J Trop Paeditric 36, 34-39.

7. Chowdhury, M.A.K.A., Banu, K., Rahman, M., 1996. Birth asphyxia- a prospective study in Dhaka Shishu Hospital. DSHJ, 125. 18-25

8. Batra A, Gupta A,Bhargava SK,Das SK.A study of asphyxia neonatorum.J obstet Gynecol Ind.2000 ;38:162-166.

9. Khreisat WH and Hababhbeh Z.Risk factors of birth asphyxia: A study at prince Ali Ben Al -Husseein Hospital,Jordan.Pak J Med Sci.2005;21(1):30-34.
10. Ariceta G, Rodríguez-Soriano J, Vallo A. Magnesium homeostasis in premature and full-term neonates. Pediatric Nephrology August 1995, Volume 9, Issue 4, pp 423-427

11. Onyiriuka AN. Prevalence of neonatal hypocalcaemia among full-term infants with severe birth asphyxia. Pacific Journal of Medical Sciences: Vol. 8, No. 1, April 2011. ISSN: $2072-1625$

12. Ilves, P., Blennow, M.,Kutt E', Magi M.L., Kudrjavtseva, G',Lagercrand, H., and Talvik, T., 1996 Concentrations of magnesium and ionized calcium in fullterm infants with hypoxic-ischemic encephalopathy. Acta Paediatr 85: 1348-50.

13. Tsang RC, Steichen JJ, Chan GM. Neonatal hypocalcemia. Mechanism of occurrence and management. Crit Care Med 1977;5: 56-61

14. Geven WB, Monnens LAH, Willems JL. Magnesium metabolism in childhood. Miner Electrolyte Metab 1993; 19: 308-13

15. Bachman KD, Feenders O, Dominick H Chr. Die klinische Bedeutung des Magnesiums in der Neugeborenenperiode. Geburtsh und Frauenheilkunde 1976; 36: 308-13

16. Shah GS, Agrawal J, Mishra OP, Chalise S. ClinicoBiochemical Profi le of Neonates with Birth Asphyxia in Eastern Nepal. J Nepal Paediatr Soc 2012;32(3):206-209.

17. Shankaran S, Laptook AR, Ehrenkranz RA, Tyson $\mathrm{JE}$, et al. National Institute of Child Health And Human Development Neonatal Research Network. $N$ Engl J Med. 2005;353(15):1574

18. Basu P, Som S, Choudhuri N, Das H (2009) Contribution of the blood glucose level in perinatal asphyxia. Eur J Pediatr 168:833-838

19. Jajoo D, Kumar A, Shankar R, Bhargava V. Effect of birth asphyxia on serum calcium levels in neonates. Indian J Pediatr 1995; 62: 455-459. 